\title{
The Vitality of Disease
}

Wahlberg, Ayo

Published in:

The Palgrave Handbook of Biology and Society

DOI:

10.1057/978-1-137-52879-7_31

Publication date:

2017

Document version

Peer reviewed version

Document license:

Unspecified

Citation for published version (APA):

Wahlberg, A. (2017). The Vitality of Disease. In M. Meloni, J. Cromby, D. Fitzgerald, \& S. Lloyd (Eds.), The Palgrave Handbook of Biology and Society (pp. 727-748). Palgrave Macmillan. https://doi.org/10.1057/978-1137-52879-7_31 


\title{
The Vitality of Disease
}

\section{Ayo Wahlberg, Department of Anthropology, University of Copenhagen}

\begin{abstract}
In recent decades, social scientists have carried out empirical studies in the laboratories, clinics and patient associations within and through which biological knowledge, biomedical practice, biosocialities and biological citizens are being co-produced. In this chapter, I sketch a novel analytics of what might be conceptualised as the vitality of disease. Medical interventions are increasingly as much about improving (quality of) life as they are about saving and prolonging life. As a consequence, morbid living has come to be disciplined, for example, in patient schools aimed at teaching patients to learn how to live with their disease, through rating scales used to measure treatment effect on the 'quality of life' of patients in clinical trials and through disease-specific 'Living with' guides aimed at patients and carers.
\end{abstract}

\section{Author bio}

Ayo Wahlberg is Professor MSO at the Department of Anthropology, University of Copenhagen. Working broadly within the field of social studies of (bio)medicine, his research has focused on traditional herbal medicine (in Vietnam and the United Kingdom), reproductive technologies (in China and Denmark) as well as health metrics (in clinical trials and global health). He is Associate Editor of BioSocieties (Palgrave Macmillan) and has recently received funding from the European Research Council for a 5-year (2015-2020) project entitled "The Vitality of Disease - Quality of Life in the Making". 


\section{Introduction}

Despite long-standing scepticism towards the biological within the social sciences (Meloni et al. 2016), in recent decades, social studies of medicine have attained a definite bio-bent as scholars have set out to map and analyse processes of biomedicalisation, molecularisation, geneticisation and pharmaceuticalisation (Lippman 1993; Clarke et al. 2009; Rose 2007; Williams et al. 2009). Such processes have urged social scientists into the laboratories, clinics and patient associations within and through which biological knowledge, biomedical practice, biosocial groupings and biological citizens are being formed, or co-produced. Anthropologists, sociologists and historians alike have taken up the task of studying biomedical practices of research, therapy and counselling both within biomedical settings and outside as biomedical knowledge, products and practices leave its laboratories, factories and clinics to circulate in communities and households (Novas 2006; Callon \& Rabeharisoa 2008; Lock 2013). ${ }^{1}$ We have learned how bio-social communities form around specific genetic mutations, how biological citizens negotiate access to entitlements and demand health rights by tactically using biological knowledge, how individuals increasingly relate to and act upon themselves in terms of their genetics or neurochemistry and how biotech CEOs mobilise capital by selling future 'visions of life' in the bio-economy. In this strand of research, "the vital politics of our century... is concerned with our growing capacities to control, manage, engineer, reshape and modulate the very vital capacities of human beings... at the molecular level" (Rose 2006, 3-4). As a result, we have a seen a proliferation of social scientific bio-concepts - from biosociality to bio-value, bio-regulation, bio-capital, bio-economy and biological citizenship - just as journals like BioSocieties and New Genetics and Society have appeared as venues for social

\footnotetext{
${ }^{1}$ Small sections of this article have appeared as an entry on the Somatosphere blog (http://somatosphere.net/).
} 
scientific scholars to engage with the ways in which a 'new' biology impacts upon society and vice versa.

Yet this turn to the social study of biology and biological knowledge production practices in medicine has not been embraced by all. Medical anthropologists (and other qualitative health researchers) who study the lived experience of their informants as they fall ill and struggle to get better, devising coping strategies and mobilizing therapy support groups along the way have pointed not to the growing circulation of biomedicine and biomedical concepts, but rather to the chronic failures of biomedicine in terms of its availability, accessibility, quality, efficacy and relevance (see Biehl \& Petryna 2013; Manderson \& Smith-Morris 2010). From these scholars, we have learned how biomedicine is but one among many medical strategies pursued by the ill and also how stark inequalities continue to shape medical landscapes throughout the world. And so, if the aforementioned bio-turn has seen social scientists take up biology and biological knowledge production as the objects of their study, 'classic' medical anthropologists have retained subjectcentred approaches to understanding therapeutic quests, illness understandings and relationalities.

In more recent years, a third form of social scientific engagement with biology and society in medical fields has emerged (Pickersgill et al. 2013; Meloni \& Testa 2014; Lock 2015). As Meloni and colleagues $(2016,10)$ have asked, "if some of the convenient notions that polarized the separation between the social and the biological as two distinctive fields are becoming increasingly untenable in the light of the new biology, what shall we make of our reassuring disciplinary division?" Indeed, the goal of the present Handbook of Biology and Society is to move beyond the acrimonious debates that have characterized the biology/society border in biology and the social sciences alike. This is a biosocial (as opposed to a bio-) turn which is characterised not so 
much by social scientists taking biology as an object of study, but rather by attempts to (re)incorporate notions of the biological body into social investigations and vice versa.

These developments notwithstanding, there is one line of analytical and empirical pursuit which remains strikingly idle, namely that which relates to the formation of knowledge of living (understood as a social activity and personal experience) and related practices of living. How biology and society intersect in the $21^{\text {st }}$ century is not only a matter of how developments in genetics, neuroscience, reproductive technologies and regenerative medicine are profoundly transforming the ways in which we organise our societies and relate to ourselves. Nor is it only a matter of how social lives and individual biographies profoundly shape our situated biologies. It is also a matter of methodologies. The medical life sciences are those which take organs, tissues, cells and DNA as their object of study predominantly with the help of microscopes, magnetic resonance imaging, polymerase chain reaction techniques, pipettes, cell cultures and the like. Social scientists on the other hand study people; their forms of organisation, their practices, behaviours, selfunderstandings and more, predominantly with the help of databases, collected documents, surveys, interviews, participant observation and more. Biology and society intersect in numerous spheres (see Villadsen \& Wahlberg 2015), albeit health and medicine is perhaps one of the most salient and it is within this sphere that I will show how knowledge of (biological) life and knowledge of living - generated in and through different methodologies - have come to co-circulate and inform practice in ways that increasingly enfeeble the kinds of epistemological hierarchisations that are embedded in the notions of 'biological reductionism', 'biomedical hegemony' or Cochrane-style hierarchy of evidence models (which place qualitative research on their lowest rungs).

Canguilhem once wrote: "Human life can have a biological meaning, a social meaning, and an existential meaning. In an assessment of the modifications that disease inflicts on 
the human being, all these meanings can equally be retained. A man does not live only like a tree or a rabbit" (2008,121-22). Point being: not only is life sustained, it is also lived. If Canguilhem's archaeological readings of biologists and medical scientists have generated path-breaking insights into the formation of "knowledge of life" in its biological meaning; what then of its social and existential meanings? I would suggest that the time is ripe for empirical analyses of the ways in which knowledge of living - that is to say knowledge of living as a social activity and a personal experience - has come to be formed, as well as how it has transmogrified or spilled over into practices of living (and vice versa) within medical arenas. For, alongside molecularisation and biomedicalisation, we have seen an upsurge in the production of knowledge about how it is to live with disease - morbid living - a subset of what I have more broadly called knowledge of living.

In distinguishing between knowledge of life and knowledge of living, I am not alluding to the distinction between 'bare life' (or zoe) and 'qualified life' (or bios), which has been extensively fleshed out by Agamben (1998), Fassin (2009), Biehl (2013) and many others who rightly point out that there is more to the politics of life than the bio prefix indexes. Neither am I pointing to the styles of ethical activity that make up contemporary 'regimes of living' (Lakoff \& Collier, 2004). Instead I am making a methodological distinction between how knowledge of life and knowledge of living are generated as well as between the DNA, cells, tissues and organs that biomedical therapies target and the identities, quality of life, daily living or wellbeing that strategies aimed at improving the lives of those living with disease target. My suggestion is that we need to study the productive effects of our own knowledge production practices as social scientists - i.e. we need to be as attentive to the effects of our interview techniques and observation as we have been to the effects of sonography or DNA amplification. 
I am not the only one to have noted this blind spot within contemporary social studies of medicine. Rabeharisoa and colleagues recently put together an important special issue on what they call 'evidence based activism' in which they argue that "patients' organisations... collect experiences and build experiential knowledge, and that is how they give shape to concerned groups and delineate their preoccupations" (2014,115). Likewise, Angela Martin and colleagues held Experience as Evidence? A Symposium on the Sciences of Subjectivity in Healthcare, Policy and Practice at the University of Oxford in October 2014 to explore "What does it take to turn experience into evidence? What new methods and expertise are emerging in this field?" More broadly, Charles Camic and colleagues have called for an expansion of STS attention to the social sciences by suggesting further studies of "the mundane actions and processes by which the makers of social knowledge carry out their work[,] ... the daily routines of knowledge production, evaluation, and use" $(2011,8)$. While I agree that we must look to the ways that qualitative evidence is currently being produced in patient associations or government agencies for use in policy and practice, I suggest that we must in a sense be bolder than this. Qualitative health research, including that of medical anthropologists and sociologists, has been around for at least a century now, and it has certainly not remained within the ivory tower. Rather (much like biomedical knowledge), it has left the Academy to circulate within hospital consultations, patient schools, households and more, as I will show. It is for these reasons that we need to attend to the effects of knowledge of living with the same commitment that the effects of knowledge of life have been cartographically and analytically pursued in recent decades.

In this chapter, I sketch out a possible outline for such an analytics of what we might conceptualise as the vitality of disease. I begin by arguing that morbid living has by now settled alongside pathological life as a crucial site of therapeutic intervention in many different medical 
settings. I then move on to argue that biological diseases today are as much understood as 'kinds of living' (Wahlberg 2009) as they are failing biologies in these same settings. Finally, I suggest that in recent decades, morbid living has come to be disciplined, by what I mean processes through which knowledge of living with a disease transmogrifies into practices of morbid living and vice versa (cf. Foucault 1995). I point to three instances of the disciplining of morbid living; firstly the emergence of patient schools aimed at teaching patients to learn how to live with their disease; secondly the standardization of subjects through rating scales used in clinical trials to measure treatment effect on the 'quality of life' of patients; and finally the dissemination of practical advice through systematized, disease-specific 'Living with'-guides aimed at patients and carers which are often prepared by patient or disease-advocacy associations. What these instances have in common is a focus on patient living as something that can be improved in terms of 'quality of life', 'wellbeing' or 'healthy life' as therapeutic objects. Indeed, quality of life has become a container concept.

\section{MORBID LIVING AND THE BIRTH OF 'QUALITY OF LIFE'}

According to epidemiologists, more people than ever before are living with (especially chronic) diseases. Against a backdrop of aging populations, 'lifestyle disease' epidemics and advances in medicine, epidemiological calculations have suggested that by 2004, " 18.6 million were severely disabled and another 79.7 million had moderate long-term disability" because of the diseases they suffered from (WHO 2008, 34; Manderson \& Smith-Morris 2010). In countries like the United Kingdom and Denmark, healthcare officials report that soaring numbers of people with long-term medical conditions such as diabetes and dementia have pushed the proportion of treating and caring costs for the chronically ill to between $70-80 \%$ of national healthcare budgets (Campbell 2014; MandagMorgen 2011). At the same time, as many scholars have pointed out low-income countries 
are currently struggling with a 'double burden' of both communicable and non-communicable disease, indeed so much so that acute-chronic and communicable-non-communicable dichotomies are becoming blurred (Rosenberg and Golden 1992; Whyte 2012; Manderson \& Smith-Morris 2010). And so, just as healthcare workers in the global North and South continue their efforts to reduce morbidity and mortality rates through preventive medicine, lifestyle interventions or curative treatment, they must also improve the lives of those living with disease, or as put in a national healthcare strategy from Denmark, they "must focus much more than hitherto on both length and quality of life" (MoH 2002, 6). As we will see, within contemporary biomedicine and healthcare it is apparent that life is treated as much more than cellular and molecular activity. Notwithstanding the important findings that have resulted from studying the effects of biomolecuralisation, as I have already noted, there has been less attention within medical science and technology studies to the equally conspicuous and contemporaneous (with molecular biology) emergence of 'quality of life'.

This is not to say that quality of life is understudied in any way, quite the contrary. It is around the middle of the $20^{\text {th }}$ century that we can locate the birth of 'quality of life', not so much as a term, but as something that can and ought to be measured, monitored, audited and improved in the medical field (see Armstrong \& Caldwell 2004; Brooks 2013; Dokumaci 2014; Wahlberg 2007; Wahlberg \& Rose 2015). Three books in particular stand out as emblematic for this birth: John Galbraith's The Affluent Society (1958), Rachel Carson's Silent Spring (1962) and Ivan Illich’s Limits to Medicine (1976). Each of these books highlighted the ways in which longer, more affluent lives (in the West), were at the same time afflicted by the smog, toxins and iatrogenic side effects that industrial societies had brought in their wake (see Wahlberg 2007, 2012). Galbraith, Carson and Illich were of course not alone; rather they participated in what, by the 1960s, had become a chorus of critiques of modernity's growing inventory of -isations (industrialisation, 
technologisation, bureaucratisation, rationalisation, globalisation, medicalisation, etc.). In the field of medicine, the developments of renal dialysis and heart transplantation have in particular been highlighted as signposts in the consolidation of concern about 'health-related quality of life'. While these two forms of therapy clearly saved lives, as Armstrong and Caldwell have shown, early commentators argued "only at considerable sacrifice to the quality of life" $(2004,364)$.

In tandem with these critiques, an incipient field of 'quality of life' (QoL) research coalesced within the fields of medicine, public health and health economics. This type of research was devoted to the definition and measurement of quality of life in the form of indices and instruments (whether generic or disease-specific) used: to measure "a patient's ability to carry on his normal activity and work" (Karnofsky \& Burchenal 1949, 197); to measure the state of health of a particular individual, group or population (Fanshel \& Bush 1970); to assess the health outcomes of a particular health intervention (Carlens \& Nou 1971); or to evaluate a particular health policy (Patrick \& Erickson 1993). Among the most important of these instruments has been the EQ-5D measure of health outcome (Brooks 1996), the QALY (Quality Adjusted Life Years) which is used to assess the extent of the benefits gained from a medical intervention in terms of survival and quality of life and the DALY (Disability Adjusted Life Years) which is used to estimate the burden of disease in a given population with particular emphasis on non-fatal outcomes, which is to say 'loss of healthy life' as distinct from the loss of life (see Wahlberg \& Rose 2015). Much of the debates and critiques that have ensued in the wake of these and other instruments of measurement have concerned the assumptions about health and valuing of life which underpin them (see Gold et al 2002; Round 2012; Kleinman \& Kleinman 1996).

More recently, Anne Marie Mol and colleague's (2002; 2008; 2010) important work on how different enactments or versions of atherosclerosis entail different ontologies as well as on how 
logics of care and choice clash in the treatment of diabetes patients has highlighted the tensions that emerge when "it is mostly [patients'] so-called 'quality of life' that improves" $(2008,70)$. Still, for Mol, 'quality of life' indicators and measures are not analysed for what they do in terms of making up a particular version of atherosclerosis or diabetes, rather she suggests that when "quality becomes a quantity" controversies are stifled $(2002,174)$.

Such critiques notwithstanding, it is clear that with improvement of 'quality of life' firmly on the medical agenda, there is much more to the politics of vitality in the $21^{\text {st }}$ century than molecular biology. For, to acknowledge such a thing as "loss of healthy life" is to show epistemological partiality towards what I have called morbid living; when healthy life is lost, it is morbid living that takes its place which in turn calls for knowledge about how it is to live with disease. This partiality is achieved through a methodological distinction between somatic, biological life (i.e. 'life itself' as many have put it, see Franklin (2000)) and personal, social life (i.e. living as a personal and social activity or experience) as separate, albeit intimately interlinked, objects of knowledge. While "knowledge of life" (Canguilhem 2008) stemming from the life sciences certainly constitutes a key component of the ways in which vitality is understood and intervened upon today in healthcare, we must also examine how knowledge of living generated especially, but not only, through qualitative social science is also contributing to the emergence of novel forms of measurable life - e.g. 'healthy life', 'quality of life' or 'wellbeing'.

Indeed, alongside biomolecularisation, we have seen an upsurge in knowledge of how it is to live with disease, a subset of knowledge of living. Medical anthropology and sociology have, of course, been at the forefront. Beginning in the first half of the $20^{\text {th }}$ century, anthropologists began generating insights into the ways in which individuals and communities experience, cope with and tackle disease and illness (Rivers 1924; Evans-Pritchard 1937). Indeed, the distinction between 
disease and illness proposed by medical anthropologists was exactly intended to shed light on an individual's experience of living with a disease: "Disease... in the... biological terms of the biomedical model is... an alteration in biological structure or functioning" whereas "illness refers to how the sick person and the members of the family or wider social network perceive, live with, and respond to symptoms and disability" (Kleinman 1988, 3, 5-6; See Mol 2002). Consequently, as Susan Whyte has argued "research on chronic conditions... has been central for the development of methods, concepts, and theories in medical anthropology" $(2012,64)$. It was long-lasting rather than acute illness that gave rise to therapeutic quests and the unfolding of personal narratives as patients looked for meaning, support and ways to cope with their conditions (Janzen 1978; Kleinman 1980; Mattingly 1998; Steffen et al. 2005; Manderson \& Morris-Smith 2010). Hence, what I am also calling for are archaeological readings of the key concepts of medical anthropology - not reflex, regulation or pathology, but rather coping, suffering, navigation, symbolic efficacy or coherence (see Wahlberg 2008).

Moreover, if morbid living begins the moment healthy life is lost, then we are led to ask just what it is - what kinds of vitality - that is considered lost, and conversely, what there is to be (re)gained via healthcare interventions. Canguilhem famously argued that "a pathological state is never a state without norms - such a thing is impossible. Wherever there is life there are norms" (Canguilhem 1994, 351). Following Geroulanos and Meyers we can see how Canguilhem relocates this lesson into the realm of 'knowledge of living' when he shows how "disease makes it impossible to live without constant reference to norms and to deficiency vis-a-vis these norms" $(2012,3)$. We might say then that there is never a state of ill health without norms, meaning that every form of (disease-specific) morbid living has its norms. As long as one is alive, not only is life sustained biologically, it is also lived socially and personally however 'diseased' this living might 
be. It is in this sense that morbid living is quintessentially biosocial. Every disease has its specificities and characteristics in terms of the kinds of biological failing that are at stake (e.g. uncontrolled cell division, faulty immune response, ineffective production of insulin) and it is these failing biologies that inevitably lead to certain kinds of living characterised by therapy, regular medication, visits to the hospital and/or reliance on medical devices which in turn can impede upon or shape daily living. Diseases are debilitating to varying degrees and in differing ways, hence, qualitative health research has shown how becoming sick will eventually impact on daily life through a range of restrictions, limitations, constraints, discomforts and/or apprehensions. These restrictions and limitations can, at the same time, be addressed more or less effectively with the help of medical therapies and/or social support, allowing some to live chronically with a given disease for years if not decades.

For all Canguilhem has taught us about how knowledge of life and knowledge of living presuppose each other, we have yet to see the kind of archaeological readings of the knowledge of living that has been generated by medical anthropologists and other qualitative health researchers over the last century or so. If Claude Bernard, René Leriche and Marie François Xavier Bichat were central empirical sources for studies of the consolidation of a knowledge of life in the $18^{\text {th }}$ and $19^{\text {th }}$ centuries (Canguilhem 1994), then William HR Rivers, Edward E Evans-Pritchard, Erwin Acherknecht and many other qualitative social scientists become essential empirical sources for similar studies of the consolidation of a knowledge of living with disease in the $20^{\text {th }}$ century (see Wahlberg 2008). It is by studying the norms of morbid living archaeologically and genealogically that we gain further insight into questions of: what is a life of 'good quality', what is a 'healthy life' and what is 'wellbeing'? 
And so, however urgent a priority saving the lives of those who die from (especially preventable) disease remains (and let us not for a second discount this urgency, not least in these times of Ebola and scandalously grave health inequality), what I am arguing is that therapeutic objectives today increasingly involve improving the daily living, quality of life or wellbeing of individuals through specific practices which can be shared, taught, trained and propagated. For, not only have we seen an upsurge in the production of knowledge about how it is to live with disease (not least by medical anthropologists and sociologists), we have also seen a swarming of practices aimed at improving the lives of those living with disease. Efforts to improve the lives (as something further to saving lives, which, as I have said remains crucially urgent) of those living with disease are to be found globally. Let us now turn our attention to three specific arenas wherein practices aimed at improving the lives of those living with disease are currently playing out.

\section{LEARNING TO LIVE WITH DISEASE}

In a hospital leaflet distributed to discharged heart patients at Hvidovre Hospital in the west of Copenhagen, an offer is made:

When you come home from the hospital after treatment for a heart disease, it can be difficult to imagine how daily life will be. Recovery takes time and you need to know how to prevent your heart disease from getting worse. In this brochure you can read about our offer of courses and training for heart patients after discharge. (Hvidovre Hospital 2010). 
Such courses have become a mainstay of many hospitals and healthcare centres (Taylor \& Bury 2007; Lindsay \& Vrijhoef 2009). The idea is to cultivate so-called "expert patients" who, in learning how best to take care of themselves and their chronic conditions, will "improve [their] quality of life and health status" (MandagMorgen 2011,35) while also hopefully reducing strains on healthcare budgets. In a 1998 Working Group report, the World Health Organisation argued that such:

therapeutic patient education should enable patients to acquire and maintain abilities that allow them to optimally manage their lives with their disease. It is therefore a continuous process, integrated in health care. It is patient-centred; it includes organized awareness, information, self-care learning and psychosocial support regarding the disease, prescribed treatment, care, hospital and other health care settings, organizational information, and behaviour related to health and illness. It is designed to help patients and their families understand the disease and the treatment, cooperate with health care providers, live healthily, and maintain or improve their quality of life. (WHO 1998, 8)

This 'outsourcing' of care by helping patients to help themselves is a crucial site in which to observe the different ways in which practices of morbid living are currently playing out. In a welfare state like Denmark, municipalities are in charge of offering patient courses to their citizens, as in the case of a municipality in Southern Zealand which offers courses for seven different patient groups: cancer, lower back pain, chronic obstructive lung disease, type 2 diabetes, obesity, stress 
and heart disease. If we take a closer look at the patient course for type 2 diabetes, stated vital objectives are to help patients:

- achieve better regulated blood sugar levels

- feel increased physical and psychological wellbeing

- with their motivation to be physically active

- gain more energy

- get a good social network which can be used after the course

We can say, then, that such patient courses are focused on improving the vitality of type 2 diabetes patients, both by coaching patients to regulate their bodies appropriately while also working to improve their wellbeing and social life. What the emergence of therapeutic patient education in the form of systematised courses highlights is a sentiment that getting a diagnosis in a hospital is not 'merely' a biomedical matter - adhere to doctor's orders, comply with treatment regimens and schedules - but it is equally a social and personal affair. With chronic disease, patients can expect to live with the condition for the rest of their lives, and their primary challenge is therefore learning how to live within the more or less narrowing constraints that a disease is seen to bring with it in the most optimal of ways. As Mattingly and colleagues have shown, such courses stand somewhat in contrast to the daily difficulties faced by many, especially those who are socioeconomically marginalised (Mattingly et al. 2011). They contrast therapeutic patient education which is very often compliance and adherence oriented (sometimes called treatment literacy), with the kinds of 'chronic homework' that patients struggle with in their daily lives. Nonetheless, what I 
wish to point out is that patient courses have become an institutionalised component of healthcare as something further to the ambulatory visits and check-ups at the General Practitioner that have long been a part of life with a chronic condition. In so-called 'resource poor' parts of the world, such courses can take the form of community treatment literacy training or workshops to help, for example, individuals with HIV to 'live positively' (Whyte et al. 2014). We need to continue studying patient courses and training, not only with a view to assessing their strengths or shortcomings, but also to examine their productive effects in the constitution of new forms of living with particular diseases.

\section{STANDARDISED SUBJECTS}

Another arena within which we can observe the consolidation of the improvement of daily living as a therapeutic objective is that of clinical trials. Therapeutic claims for a drug or therapy are increasingly linked to the improvement of patient's 'quality of life'. For example, six out of the top ten blockbuster drugs from 2006 purported to improve patients' quality of life as their main claim: e.g. "Advair significantly improved and maintained health-related quality of life"; "Subjects treated with venlafaxine [Effexor] noted an...improved quality of life as compared to those receiving placebo"; "After treatment with Nexium $91 \%$ of patients with reflux esophagitis in the study shown here were free of heartburn, resulting in a considerable improvement in many aspects of their daily lives"; "Olanzapine [Zyprexa] demonstrated a superiority over risperidone in... improving patient quality of life and interpersonal relationships" (see Herper \& Kang 2006). Such therapeutic claims are not possible without rating scales and indices. Since treatments are not only used to save/lengthen life, researchers must be able to measure improvements in the way a patient experiences or lives with a disease, which in turn requires scales to rate what is sometimes called 
the 'health-related quality of life' of a patient. As noted earlier, we can trace the emergence of rating scales to the work of Steinbrocker and colleagues (1949) who proposed classificatory schemes for measuring the functional capacity in rheumatoid arthritis as well as Karnofsky and Burchenal (1949) who developed a performance scoring system for measuring the ability of cancer patients to carry out activities of daily living (see Wahlberg \& Rose 2015; Dokumaci 2014). Since then, the construction of such scales has become a veritable industry in itself as a cascade of generic as well as disease-specific rating scales have emerged.

What they have in common is that they attempt to quantify the subjective experience of what it is like for someone to live with a disease, i.e. what is morbid living like? Put in another way, they attempt to quantify the 'loss of healthy life'. If disease is considered to be debilitating in varying degrees and becoming sick will eventually impact on your daily life through a range of restrictions, limitations, constraints, discomforts and apprehensions, by scoring and ranking these, rating scales provide a numerical basis for assessing disease impact along axes of severity. While not exhaustive, it is possible to identify four important domains of daily living that are assessed through rating scales:

1) Functional ability - many rating scales give priority to 'performance' or the ability to carry out daily activities such as self-care (washing, toilet visits), mobility, cleaning, cooking, shopping, etc. Continuums go from 'bedridden' or 'entirely dependent' to 'fully mobile' or 'independent'. In Karnofsky and Burchenal's words, performance scales "measure the usefulness of the patient or the burden that he represents to his family or society" $(1949,195-197)$, and have been criticised for this utilitarian view of disease impact. 
2) Discomfort - not only is sickness seen to limit or constrain, it is also seen to generate discomfort, a point that many rating scales attempt to capture by asking patients to what extent they feel pain or discomfort. Continuums go from extreme pain/suffering to no pain or discomfort.

3) Unease - some rating scales attempt to capture the many apprehensions that sickness can generate in a patient. Continuums range from 'very anxious or depressed' to 'not anxious or depressed'.

4) Relationships - a less common domain is that of relationships which suggests that a 'healthy' person is one who is involved in a number of positive relationships with family, friends and colleagues. Continuums can be organised along degrees of isolation (i.e. number of relationships) as well as on how individuals self-assess their relationships (e.g. as good or bad).

Social studies of randomised controlled trials have shown how such trials rely on the construction of standardised inclusion criteria, treatment regimens as well as clinical outcomes (Lakoff 2007; Petryna 2007; Wahlberg \& McGoey 2008). Indeed, it is not uncommon for trial conductors to include a battery of clinical outcome measures in the form of rating scales as a way to maximise the possibility that some kind of 'signal' is detected, i.e. statistically significant changes in the rating scale scores of trial subjects over time. Rating scales make it possible to quantify the experience of living with disease. Yet each disease has its specificities in terms of how it is seen to impact on a patient and/ or carer. As such disease-specific scales such as the St. George's Respiratory Questionnaire (SGRQ) or the Quality of Life in Reflux and Dyspepsia (QOLRAD) have been developed for use in clinical trials for asthma and reflux respectively. Predictably, such efforts to quantify the qualitative have been subject to countless critiques. My task here is not to assess their suitability or validity rather I am highlighting the fact that knowledge about morbid living (about how it is to live with a disease) is now routinely generated in clinical trials. The rating 
scales themselves have been developed by clinicians, yet a key question emerges around how disease impact has come to be conceptualised around the four domains of functional ability, discomfort, unease and social isolation. Here we see one of the immediate methodological differences when compared to those social studies of biomedicine which have studied the coproduction of biomedical knowledge and practice: while clinicians and laboratory scientists are in specific medical settings on a daily routine basis (and therefore can more readily be observed and studied in these settings), social scientists are usually not. Moreover, while biological disease categories and substances are surrounded by visible materialities in the form of laboratory equipment, biopsies and medical devices, knowledge of quality of life is most often paper-based in the form of QoL questionnaires, study results or clinical trial protocols. The question I would pose then is, when clinicians, epidemiologists, health economists and others have developed rating scales for measuring a patient's quality of life when living with a disease, has this development been entirely independent of medical anthropologists' and other qualitative health researchers' longstanding engagements with similar questions? Future studies could productively track down the genealogies of QoL rating scales while also attending clinical meetings in which clinical trials are designed and treatment outcomes determined. The ironies of quantifying the qualitative as patients and carers are modelled into standardised subjects are obvious. Yet, we should nevertheless investigate how it is that clinicians, epidemiologists and health economists have come to invest so much time and resources into quantifying the qualitative in ways that render 'quality of life' and 'wellbeing' - the patient perspective - auditable.

\section{KINDS OF LIVING}


Life with Alzheimer's is a shared concern for both the one who has the disease and her or his loved ones. Alzheimer's infiltrates deep into family life. Roles transform and ways of being together change character. Hence, when a diagnosis has been given, the challenge is to find out how you will live a life with Alzheimer's together... Whether you have Alzheimer's or are a loved one, you will need good advice as well as help and guidance to the different phases that you will go through as the disease progresses. (From carer guide "Lev med demens [Living with dementia]", Alzheimer Association 2012)

How can one live a life of good quality - or at least the best life possible - with Alzheimer's, diabetes, chronic obstructive pulmonary disease or ischemic heart disease? Such questions lie at the heart of a new style of advice or guidance that is emerging out of especially patient associations. So-called "Living with" guides are now a standard offer from most patient associations ${ }^{2}$ as they seek to provide recently diagnosed patients and their carers with insights into the 'new' life that awaits them. Take Alzheimer's disease, a disease that is viewed by many public health experts as a major health care challenge in coming years as populations age. 'Living with dementia' guides are often introduced with the following kinds of statements: "When receiving a dementia diagnosis, you are inevitably thrown off course"; "Receiving a diagnosis of Alzheimer's is never easy — it's life changing" (Alzheimer's Asociation 2012, 3; Alz.org 2014). Such guides from patient associations contribute to the stabilisation of Alzheimer's as a 'kind of living' (Wahlberg 2009; see also Moreira et al. 2014). While each patient is unique as are his or her circumstances, there are nevertheless a range of experiences that are seen as common to the kind of living that Alzheimer's brings with it. So what kind of living is Alzheimer's? Let us take a closer look at how Alzheimer's living is

\footnotetext{
2 Tip: type "Living with..." followed by almost any disease into a search engine and see what happens.
} 
sketched out in such guides as well as how advice and tips are provided: "There are some practical things that you can do to help you live as well as possible.” (Alzheimer’s Society 2012, 42)

Common to 'Living with' guides is their emphasis on daily living and on providing tips for easing this in the face of the challenges that Alzheimer's living can bring with it. As a form of morbid living, Alzheimer's has its specificities related to memory loss, mood changes, loss of balance, medicines, doctor's appointments, the making of wills and eventually loss of ability to carry out tasks in everyday life. As a degenerative disease with no known cure, a life with Alzheimer's is characterised by a series of deteriorations which can hopefully be slowed down and tackled through medication, tips of keeping daily routines, staying active, labelling things, using a calendar, and the like.

Such guides are also characterised by their emphasis of bringing patient experiences to the fore, through quotations such as "You must carry on doing the things you enjoy, and not side line yourself from your friends and family or clubs and groups. We've always led busy lives, going out and about - and we still do.” (Alzheimer's Society 2012, 42). Indeed, as Rabeharisoa and colleagues have argued "patients' organisations... collect experiences and build experiential knowledge, and that is how they give shape to concerned groups and delineate their preoccupations" $(2014,115)$. This, they suggest, is different from the forms of biosociality that bring people together because of e.g. a shared genetic mutation (see Epstein 1998; Rabinow 1996; Rose \& Novas 2005; Gibbon \& Novas 2008). However, while Rabeharisoa and colleagues point to the 'evidence based activism' that experiential knowledge then feeds into, I would argue that we might speak of socialities which are coalescing around shared kinds of morbid living or lebens-socialities. The point being that through the generation of knowledge about what it is like to live with disease, patient associations are preparing practical advice on how best to live with that disease. It is 
therefore exactly at the intersections of knowledge and practice that we can observe what I have called a disciplining of morbid living. Morbid living is disciplined in the dual sense of coming to be the object of specialised bodies of expertise while at the same time being subject to normalising interventions aimed at promoting 'good' ways of living with a particular disease through 'living with' guides, training courses or state-led information campaigns. Much like hospitals, one Alzheimer Association organises weekend courses as well as patient schools, as they suggest growing numbers of people:

receive a dementia diagnosis while they are still leading active lives. For many, the diagnosis may lead them to stop exercising or to withdraw from their social lives. Further to decreasing a person's quality of life, isolation and inactivity can worsen the disease. That's why Alzheimer Association organises patient schools which are tailored for people with dementia. The courses are especially targeted at younger persons with early onset Alzheimer's. (Alzheimer Association 2014)

The methodological challenge here for future studies relates to examining how living with guides have been developed as well as how patient schools are designed and held. For example, in Denmark patient associations have become an important employer for anthropologists and other social scientists, not least because of their interest in patient perspectives and the ways in which patients and carers live with disease on a daily basis. Who are the experts hired to put together "Living with" guides, and what forms of knowledge and expertise are invoked to qualify daily 
living advice? Once again methodological challenges arise, ones requiring detective-like skills of tracking down how morbid living manuals and patient schools have been developed.

\section{CONCLUSION - LIVING}

Why research the ways in which morbid living has come to be known and practiced when in many ways it is its opposite in 'healthy living' that has recently grabbed headlines and shaped numerous national health agendas in the form of preventative medicine (e.g. cholesterol and blood pressure medicines), lifestyle interventions (targeting exercise, alcohol and smoking) or nutrition campaigns (e.g. five-fruits-a-day) (see Greene 2007; Dumit 2012)? Firstly, as pointed out in this chapter, notwithstanding continued efforts to reduce morbidity and mortality, when it comes to healthcare, it is long-term disease treatment and management that is taking a growing share of annual healthcare expenditure. We can say that the management and improvement of morbid living is one of the most pressing tasks for healthcare workers today. Indeed a national healthcare administrator in the United Kingdom has warned that "this is the biggest problem facing the health system and the care system and the costs are growing year on year... unless we change the way we address the problems, [it] will overwhelm the system" (McShane cited in Campbell 2014).

Secondly, by studying how morbid living is known and practiced, we can also generate further insight into how healthy living and quality of life (as healthcare objectives) are understood and how they are valued. At stake are efforts to enable the best possible lives within the constraints that particular diseases are seen to bring with them not by privileging either biomedicine or social science, rather by acknowledging that both are requisite. In the biosocial turn that this book is in part a response to, methodological debates often concern how social and biological research 
techniques can be modified to take the other into account, for example in the form of a bioethnography "which integrates biological and ethnographic data about the larger histories and life circumstances that shape health" (Roberts 2015). What I am proposing is to make ethnographic and other forms of qualitative research the object of study in much the same way that social scientists have made biological knowledge production the object of research in recent decades. If medical practice today is informed in important ways by qualitative insights into how it is to live with disease, then social studies of medicine will do well to train their analytical gaze in equal measure towards the production of knowledge that takes place within the social sciences.

How then should one design research that will allow one to research the disciplining of morbid living? To begin with, we must ensure that we are empirically equipped to study the ways in which knowledge of morbid living is generated on the one hand, and on the other, how practices of morbid living are shaped and 'routinised' which requires homing in on the knowledge/practice nexus.

Chosen empirical sites must therefore, on the one hand, provide an opportunity to study the ways in which 'quality of life' or 'healthy life' is known, measured and invoked as a metric of morbid living along good/bad or better/worse continuums. They must also allow one to examine how patients and carers seek out, share and receive tips, advice or training about how best to live with a particular disease - how to get on when afflicted by a particular condition. Such an approach marks a break from hitherto social studies of biomedicine which have focused on molecularisation and the forms of biosociality and biological citizenship that have emerged in its wake.

I should reiterate once again that it is not my claim that 'quality of life', 'wellbeing' or 'healthy living' has been understudied in any way. As I have underlined, medical anthropologists and other qualitative social scientists have been researching such themes for over a century. Indeed, in a sense I am suggesting that perhaps qualitative health research deserves far more credit than it has 
received. Medical anthropology, for example, is not 'merely' a subjective discipline operating in the shadows of and critiquing a hegemonic biomedicine. It is a field of expertise that has contributed in concrete ways to the transformation of medical practice, in GP consultations, hospitals, patient associations as well as homes. If this is the case, what we need are methodological tools to trace the ways in which knowledge of morbid living has come to co-circulate (alongside biomedical knowledge of disease) and transmogrify into practices of morbid living.

Of course, one of the open questions that such an approach raises is the extent to which we can find links between the qualitative insights that have been generated over the past century or so about how people live with, cope with and tackle disease and illness and the ongoing efforts to know morbid living through, for example, clinical trials or patient associations. This will require empirical studies of the co-production of medical practices which aim to improve the quality of life of patients and carers.

\section{Acknowledgments}

I would like to thank the editors for comments which have improved this chapter considerably. The chapter was prepared within the framework of the European Research Council grant "The Vitality of Disease - Quality of Life in the Making” (Grant no. 639275).

\section{Literature}

Agamben, Giorgio.1998. Homo Sacer: Sovereign Power and Bare Life. Stanford: Stanford University Press. 
Wahlberg, A 2017. 'The Vitality of Disease'. in M Meloni, J Cromby, D Fitzgerald \& S Lloyd (eds), Handbook of Biology and Society. Palgrave Macmillan, pp. 727-748.

Alzheimer Association.2012. Livet med demens [Living with dementia]. http://www.alzheimer.dk/raad/livet-med-demens. Accessed on 10 October 2012.

Alzheimer’s Society.2012. The Dementia Guide: Living Well After Diagnosis. London.

Armstrong, David \& Rachel Caldwell.2004. Origins of the Concept of Quality of Life in Health Care: A Rhetorical Solution to a Political Problem. Social Theory \& Health. 2: 361-371.

Biehl, Joao., \& Petryna, Adriana. (Eds.). 2013. When people come first: critical studies in global health. Princeton University Press.

Brooks, Ricahrd.2013.The EuroQol Group after 25 years. Berlin: Springer.

Callon, Michel, \& Rabeharisoa, Vololona. 2008. The growing engagement of emergent concerned groups in political and economic life: Lessons from the French association of neuromuscular disease patients. Science, Technology, \& Human Values, 33(2), 230-261.

Camic, Charles, Gross, Neil, Lamont Michele.2011. Social Knowledge in the Making. Berkeley: University of California Press.

Campbell, David.2014. NHS Could Be 'Overwhelmed' by People with Long-Term Medical Conditions. The Guardian, January 3, sec. Society. http://www.theguardian.com/society/2014/jan/03/nhs-overwhelmed-long-term-medicalconditions. (accessed on 15 January 2014).

Canguilhem, Georges.1991. The Normal and the Pathological. New York: Zone Books.

Canguilhem, Georges.1994. A Vital Rationalist: Selected Writings from Georges Canguilhem. New York: Zone Books. 
Wahlberg, A 2017. 'The Vitality of Disease'. in M Meloni, J Cromby, D Fitzgerald \& S Lloyd (eds), Handbook of Biology and Society. Palgrave Macmillan, pp. 727-748.

Canguilhem, Georges.2008. Knowledge of Life. New York: Fordham University Press.

Canguilhem, Georges.2012. Writings on Medicine. Translated by Stefanos Geroulanos and Todd Meyers. 2 edition. New York: Fordham University Press.

Carlens ED Gunnar, Nou, Enn.1971. An attempt to include "quality of life" in evaluation of survival in bronchial cancer therapy. Bronches 21:215-219

Clarke, Adele E, Laura Mamo, Jennifer Ruth Fosket, Jennifer R. Fishman, Janet K. Shim. 2009 Biomedicalization: Technoscience, Health, and Illness in the U.S. Duke University Press

Cohen, Lawrence.1995. “Toward an Anthropology of Senility: Anger, Weakness, and Alzheimer's in Banaras, India." Medical Anthropology Quarterly 9 (3): 314-34.

Collier, Stephen J., and Andrew Lakoff.2007. “On Regimes of Living.” In Global Assemblages, edited by Aihwa Ong and Stephen J. Collier, 22-39. Blackwell Publishing Ltd.

Dokumaci, Arseli.2014. 'Performance as Evidence in Chronic Disease: Measuring health status and treatment outcomes through the quantification of performance'. Performance Research: A Journal of the Performing Arts, 19(4): 14-23

Dumit, Jo.2012. Drugs for Life: How Pharmaceutical Companies Define Our Health. Durham: Duke University Press.

Epstein, Stephen.1998. Impure Science: AIDS, Activism, and the Politics of Knowledge. Berkeley: University of California Press. 
Wahlberg, A 2017. 'The Vitality of Disease'. in M Meloni, J Cromby, D Fitzgerald \& S Lloyd (eds), Handbook of Biology and Society. Palgrave Macmillan, pp. 727-748.

Estroff, Sue E.1993. Identity, disability, and schizophrenia: The problem of chronicity. In Lindenbaum S, Lock M (Eds.) Knowledge, power, and practice: The anthropology of medicine and everyday life. Berkeley: University of California Press. pp. 247-286.

Evans-Pritchard, Evans E.1937. Witchcraft, Oracles and Magic among the Azande. Oxford: Clarendon Press.

Fanshel S, Bush JW.1970. A health-status index and its application to health services outcomes. Operations Research 18(6): 1021-1066.

Fassin, Didier.2009. “Another Politics of Life Is Possible.” Theory, Culture \& Society 26 (5): 4460.

Foucault, Michel.1994. The Birth of the Clinic: An Archaeology of Medical Perception. New York: Vintage.

Foucault, Michel.1995. Discipline \& Punish: The Birth of the Prison. Translated by Alan Sheridan. 2nd edition. New York: Vintage Books.

Fox, Nick .J. and Katie J. Ward.2009. 'Pharma in the Bedroom ... and the Kitchen ... The Pharmaceuticalisation of Daily Life', in S.J. Williams, J. Gabe and P. Davis (eds) Pharmaceuticals and Society, pp. 41-53. Chichester: Wiley-Blackwell.

Franklin, Sarah.2000. Life itself - global nature and the genetic imaginary. In Franklin S, Lury C \& Stacey J (Eds.) Global Nature, Global Culture. London: Sage, pp.188-227

Geroulanos, Stefanos and Meyers, Todd.2012. Introduction. In Canguilhem, Georges. 2012. Writings on Medicine. Translated by Stefanos Geroulanos and Todd Meyers. 2 edition. New York: Fordham University Press. 
Wahlberg, A 2017. 'The Vitality of Disease'. in M Meloni, J Cromby, D Fitzgerald \& S Lloyd (eds), Handbook of Biology and Society. Palgrave Macmillan, pp. 727-748.

Gibbon, Sahra \& Novas, Carlos (Eds.)2008. Biosocialities, Genetics and the Social Sciences: Making Biologies and Identities. London: Routledge

Gold, Marthe, Stevenson, David, Fryback, Dennis.2002. HALYS and QALYS and DALYS, oh my: similarities and differences in summary measures of population health. Annual Review of Public Health 23: 115-34

Good, Byron J.1994. Medicine, Rationality, and Experience: An Anthropological Perspective. Cambridge: Cambridge University Press.

Greene, Jeremy.2007. Prescribing by Numbers: Drugs and the Definition of Disease. Baltimore: Johns Hopkins University Press.

Hacking, Ian.2004. Historical Ontology. Cambridge, MA: Harvard University Press

Herper, Matthew \& Kang, Peter.2006.“The World's Ten Best-Selling Drugs.” Forbes. Accessed 10 February 2013. http://www.forbes.com/2006/03/21/pfizer-merck-amgencx_mh_pk_0321topdrugs.html.

Herskovits, Elizabeth.1995. "Struggling over Subjectivity: Debates about the 'Self' and Alzheimer's Disease.” Medical Anthropology Quarterly 9 (2): 146-64.

Hvidovre Hospital.2010. Efterbehandling i Kardiologisk Klinik - Hjerterehabilitering. Hvidovre: Hvidovre Hospital.

Illich Ivan.1976. Limits to Medicine : Medical Nemesis, the Expropriation of Health. London: Boyars. 
Wahlberg, A 2017. 'The Vitality of Disease'. in M Meloni, J Cromby, D Fitzgerald \& S Lloyd (eds), Handbook of Biology and Society. Palgrave Macmillan, pp. 727-748.

Ivry, Tsipy.2009. The Ultrasonic Picture Show and the Politics of Threatened Life. Medical Anthropology Quarterly 23(3):189-211.

Janzen, Jonathan M.1978. The Quest for Therapy in Lower Zaire. Berkeley: University of California Press

Karnofsky, David A \& Burchenal, John H.1949. The Clinical Evaluation of Chemotherapeutic Agents in Cancer. In: MacLeod CM (Ed), Evaluation of Chemotherapeutic Agents. Columbia Univ Press. Pp. 196-98.

Kaufman, Sharon R, Morgan, Lynn M.2005. The Anthropology of the Beginnings and Ends of Life. Annual Review of Anthropology 34:317-41.

Kleinman, Arthur.1980. Patients and Healers in the Context of Culture. Berkeley: University of California Press

Kleinman, Arthur. 1988. The Illness Narratives: Suffering, Healing, and the Human Condition. New York: Basic Books.

Kleinman, Arthur, and Joan Kleinman.1996. "The Appeal of Experience; The Dismay of Images: Cultural Appropriations of Suffering in Our Times.” Daedalus 125 (1): 1-23.

Lakoff, Andrew.2007. The Right Patients for the Drug: Managing the Placebo Effect in Antidepressant Trials. BioSocieties 2 (1): 57-71.

Leibing, Annette.2009. “Tense Prescriptions? Alzheimer Medications and the Anthropology of Uncertainty." Transcultural Psychiatry 46 (1): 180-206. 
Wahlberg, A 2017. 'The Vitality of Disease'. in M Meloni, J Cromby, D Fitzgerald \& S Lloyd (eds), Handbook of Biology and Society. Palgrave Macmillan, pp. 727-748.

Lezaun, Javier.2007. A market of opinions - the political epistemology of focus groups. Sociological Review 55: 130-151.

Lindsay, Sally \& Vrijhoef, Hubertus JM.2009. A Sociological Focus on `expert Patients’. Health Sociology Review 18 (2): 139-44.

Lippman, Abby. 1993. Prenatal Genetic Testing and Geneticization: Mother Matters for All, Fetal Diagn Ther 8 (suppl 1), 175-188.

Lock, Margaret.2013. The Alzheimer Conundrum: Entanglements of Dementia and Aging. Princeton: Princeton University Press

Lock, Margaret. 2015. Comprehending the body in the era of the epigenome. Current Anthropology, 56 (2): 151-177.

MandagMorgen.2011. Kommuner og Kronikere: Bedre Pleje og Behandling i Eget Hjem. Copenhagen: Rosendahls.

Manderson, Leonore. and Smith-Morris, Carolyn. (eds) 2010. Chronic Conditions, Fluid States: Chronicity and the Anthropology of Illness. New Brunswick: Rutgers UP.

Marcus, George E.1995. Ethnography in/of the World System: The Emergence of Multi-Sited Ethnography. Annual Review of Anthropology 24: 95-117.

Mattingly, Cheryl .1998. Healing Dramas and Clinical Plots: The Narrative Structure of Experience. Cambridge: Cambridge University Press.

Mattingly, Cheryl, Lone Grøn, and Lotte Meinert. 2011. "Chronic homework in emerging borderlands of healthcare." Culture, Medicine, and Psychiatry 35(3): 347-375. 
Wahlberg, A 2017. 'The Vitality of Disease'. in M Meloni, J Cromby, D Fitzgerald \& S Lloyd (eds), Handbook of Biology and Society. Palgrave Macmillan, pp. 727-748.

Meloni, Maurizio. and Testa, Giovanni. 2014. Scrutinizing the epigenetics revolution. BioSocieties, 9: $431-456$.

Meloni, Maurizio., Williams, Simon, \& Martin, Paul. 2016. The biosocial: sociological themes and issues. The Sociological Review Monographs, 64(1), 7-25.

Meyers, Todd.2007. “A Turn towards Dying: Presence, Signature, and the Social Course of Chronic Illness in Urban America.” Medical Anthropology 26, no. 3 (September 2007): 205-27.

MoH.2002. Sund hele livet [Healthy for Life]. Danish Government. Ministry of Health: Copenhagen.

Mol, Anne Marie.2002. The Body Multiple: Ontology in Medical Practice. Durham: Duke University Press.

Mol, Anne Marie.2008. The Logic of Care: Health and the Problem of Patient Choice. Milton Park: Oxford: Routledge.

Mol, Annemarie, Ingunn Moser, and Jeannette Pols.2015. Care in Practice: On Tinkering in Clinics, Homes and Farms. transcript Verlag, 2015.

Moreira, Tiago, Orla O’Donovan, and Etaoine Howlett.2014. “Assembling Dementia Care: Patient Organisations and Social Research.”BioSocieties 9 (2): 173-93.

Nguyen Vinh Kim.2010. Republic of Therapy : Triage and Sovereignty in West Africa's Time of AIDS. Durham: Duke University Press. pp.89-110.

Novas, Carlos. 2006. The political economy of hope: Patients' organizations, science and biovalue. BioSocieties, 1(3), 289-305. 
Wahlberg, A 2017. 'The Vitality of Disease'. in M Meloni, J Cromby, D Fitzgerald \& S Lloyd (eds), Handbook of Biology and Society. Palgrave Macmillan, pp. 727-748.

Ong Aiwha, Collier, Stephen.2005. Global Assemblages: Technology, Politics, and Ethics as Anthropological Problems. Malden: Blackwell.

Patrick, Donald L, Erickson, Peniffer.1993. Health Status and Health Policy: Quality of Life in Health Care Evaluation and Resource Allocation. New York: Oxford University Press

Petryna, Adriana.2002. Life Exposed: Biological Citizens after Chernobyl. Princeton: Princeton University Press.

Petryna, Adriana.2007. Clinical Trials Offshored: On Private Sector Science and Public Health. BioSocieties 2(1): 21-40.

Pickersgill, Martin, Jörg Niewöhner, Ruth Müller, Paul Martin, and Sarah Cunningham-Burley. 2013. Mapping the new molecular landscape: social dimensions of epigenetics. New Genetics and Society 32(4): 429-447.

Rabeharisoa Vololona, Callon, Michel.2002. The involvement of patients' associations in research. International Social Science Journal 54(171): 57-63

Rabeharisoa, Vololona, Moreira, Tiago, Akrich A.2014.Evidence-based activism: Patients', users' and activists' groups in knowledge society. BioSocieties 9(2): 111-128

Rabinow, Paul.1996. Essays on the Anthropology of Reason. Princeton, N.J: Princeton University Press.

Rajan, Kaushik Sunder.2006. Biocapital: The Constitution of Postgenomic Life. Durham: Duke University Press.

Rivers, William HR.1924. Medicine, Magic and Religion. London: Kegan Paul, Trench, Trubner. 
Wahlberg, A 2017. 'The Vitality of Disease'. in M Meloni, J Cromby, D Fitzgerald \& S Lloyd (eds), Handbook of Biology and Society. Palgrave Macmillan, pp. 727-748.

Roberts, Elizabeth FS. 2015. Bio-Ethnography: A Collaborative, Methodological Experiment in Mexico City. Somatosphere, 26 February 2015, http://somatosphere.net/2015/02/bioethnography.html, accessed on 7 February 2017

Round, Jerome.2012. Is a QALY still a QALY at the end of life? Journal of Health Economics 31(3): 521-527

Rose, Nikolas.2007. The Politics of Life Itself: Biomedicine, Power, and Subjectivity in the TwentyFirst Century. Princeton: Princeton University Press.

Rose, Nikolas \& Novas, Carlos.2005. Biological Citizenship. In Ong A \& Collier S (Eds.) Global Assemblages: Technology, Politics and Ethics as Anthropological Problems. Malden, MA: Blackwell, pp.439-464

Shomaker, Dianna J.1989. “Age Disorientation, Liminality and Reality: The Case of the Alzheimer's Patient.” Medical Anthropology 12, no. 1 (November 1, 1989): 91-101.

Steffen Vibeke, Jessen, Hanne, Jenkins, Richard (eds).2005. Managing Uncertainty. Ethnographic Studies of Illness, Risk, and the Struggle for Control. Copenhagen: Museum Tusculanums Press.

Villadsen, Kaspar, \& Wahlberg, Ayo. (2015). The government of life: managing populations, health and scarcity. Economy and Society, 44(1), 1-17.

Wahlberg, Ayo.2007.Measuring progress: calculating the life of nations. Distinktion: Scandinavian Journal of Social Theory, 14: 65-82

Wahlberg, Ayo.2008. Above and beyond superstition: western herbal medicine and the decriminalising of placebo. History of the Human Sciences, 21(1): 77-101. 
Wahlberg, A 2017. 'The Vitality of Disease'. in M Meloni, J Cromby, D Fitzgerald \& S Lloyd (eds), Handbook of Biology and Society. Palgrave Macmillan, pp. 727-748.

Wahlberg, Ayo.2009, Serious Disease as Kinds of Living. in S Bauer \& A Wahlberg (eds), Contested Categories: Life Sciences in Society. Ashgate, Burlington, pp. 89-112.

Wahlberg, Ayo \& Rose, Nikolas.2015, 'The governmentalization of living: Calculating global health' Economy and Society, vol 44, no. 1, pp. 60-90.

WHO.1992. Global Health Situation and Projections_-Estimates. Division of Epidemiological Surveillance and Health Situation and Trend Assessment. Geneva: WHO.

WHO.1998. Therapeutic patient education: continuing education programmes for health care providers in the field of prevention of chronic diseases: report of a WHO working group.

WHO.2008. 2008-2013 Action Plan for the Global Strategy for the Prevention and Control of Noncommunicable Diseases. Geneva: WHO Press

Williams, Simon, Gabe, Jonathan, \& Davis, Peter. 2009. Pharmaceuticals and society: Critical discourses and debates. John Wiley \& Sons.

Whyte Susan R.2012. Chronicity and control: framing 'noncommunicable diseases' in Africa. Anthropology \& Medicine 19(1): 63-74.

Whyte, Susan R (Ed).2014. Second Chances: Surviving AIDS in Uganda. Durham: Duke University Press. 